\author{
St ud a P hiloso phic a \\ Wratis l avie n s i a \\ vol. XV, fasc. $4(2020)$
}

https://doi.org/10.19195/1895-8001.15.4.9

\author{
ZBIGNIEW PIETRZAK \\ ORCID: 0000-0003-2458-1252 \\ Uniwersytet Wrocławski
}

\title{
Ewolucja piękna. O wspólnocie przeżyć estetycznych zwierząt i ludzi
}

Richard O. Prum, Ewolucja piękna. Jak darwinowska teoria wyboru partnera kształtuje świat zwierząt $i$ nas samych, tłum. K. Skonieczny, Copernicus Center Press, Kraków 2019, ss. 435.

Wielu przyrodników wychodzi poza swoją wąską specjalizację i formułuje idee, które - choć oparte na wnioskach płynących z ich specjalistycznych badań ukazują przyrodę w szerszej perspektywie i odmiennym kontekście. Tworzą tym samym przestrzeń do pozaprzyrodniczej interpretacji obserwowanych i badanych zjawisk natury. Ową perspektywę można nazwać filozoficzną, psychologiczną, społeczną, a nawet polityczną. Aby zilustrować to zjawisko, wystarczy wskazać na refleksje takich współczesnych uczonych, jak Konrad Lorenz, Ernst Mayr, Edward O. Wilson czy P. Godfrey-Smith ${ }^{1}$. Każdy z nich wprowadził do swoich specjalistycznych badań filozoficzną perspektywę wykraczającą poza reprezentowaną dziedzinę i stosowaną metodologię. W ten sposób powstała etologia, w ten sposób biolodzy zaczęli dyskutować o ontologii gatunku biologicznego, pojawiła się idea socjobiologii, a w końcu koncepcja nowoczesnej filozofii biologii.

Pisząc o jednym z najbardziej złożonych aspektów ekologii i behawioru ptaków, jakim jest ich biologia rozrodu, Richard O. Prum pisze także o ludziach. W książce pojawiają się kwestie dotyczące obecności polityki w nauce, kwestie metodologiczne i w konsekwencji problemy z filozofii nauk przyrodniczych.

\footnotetext{
1 Por. K. Lorenz, Odwrotna strona zwierciadła, Warszawa 1977; E. Mayr, The Ontological Status of Species, „Biology and Philosophy” 2 (1987), by D. Reidel Publishing Company; E.O. Wilson, Sociobiology - The New Synthesis, Cambridge, MA 1975; P. Godfrey-Smith, Philosophy of Biology, Princeton-Oxford 2016; P. Griffiths, K. Stotz, Philospphy of Genetics, Cambridge 2013.
} 
Formułowanie mniej lub bardziej zasadnych i trafnych analogii między światem ptaków (szerzej - światem zwierząt, a nawet roślin) oraz światem ludzi jest dość powszechne, sama zaś perspektywa odkrywania związków między tak odległymi przyrodniczo bytami jest kusząca. Związane z ptasim okresem godowym tańce, śpiewy, barwne, lśniące upierzenie, wyszukana, wzorzysta ornamentyka były powodem, dla którego ten aspekt życia ptaków fascynował nie tylko przyrodników, ale także artystów, szczególnie malarzy, filozofów, a nawet teologów, co znajdowało swoje odbicie w bestiariuszach. Budowa gniazd, opieka rodzicielska, różnorodność relacji partnerskich związanych z rozrodem, monogamia oraz poligamia: poliandria i poligynia, a także promiskuityzm i różnorodność związków funkcjonujących po okresie godowym - to wszystko sprzyjało antropomorfizacji w pracach nie tylko ornitologicznych. Wszystkie bowiem elementy dotyczące zachowań i „fizyczności”" w sferze seksualnej, które występują wśród ptaków, odnajdujemy także w świecie ludzi. Tańce i śpiewy, „język miłosny”, choćby w poezji, „odświętność godowa” stroju na rendez-vous czy ubioru ślubnego, szczególna fizjologiczno-biologiczna „szata” pojawiajacca się w okresie dojrzewania (na przykład zarost, owłosienie łonowe, zmiany proporcji ciała) i oczywiście towarzysząca tym wszystkim osobniczym aspektom presja kulturowa oraz religijna, której odpowiednik w świecie ptaków znajdujemy w zrytualizowanym behawiorze mającym ewolucyjne (filogenetyczne) źródła, prowokują do budowania takich analogii. Sądzę jednak, iż najczęściej są one nie tylko powierzchowne, ale mają również publicystyczno-popularyzatorski charakter i są metodologicznie oraz epistemologicznie nieuzasadnione.

Prum to biolog i ornitolog terenowy, posiada wiedzę płynącą z obserwacji niedostępnych nie tylko przeciętnemu miłośnikowi ptaków, ale i wielu zawodowym ornitologom. Formułując zatem paralelę między ptakami a ludźmi, odwołuje się do relacji, które wynikają z mało znanych aspektów zachowania, ekologii i biologii rozrodu ptaków. Poszukiwanie związków między ornitologicznymi i antropologicznymi „wątkami” jest więc zamierzone, a nie przypadkowe. Badajacc i interpretując zachowania godowe (strategie rozrodcze) wielu gatunków ptaków ${ }^{2}$ oraz formułując analogie między ich zachowaniem a zachowaniem ludzi, wykorzystuje kontrowersyjną hipotezę „Piękno się Zdarza”. Pomijając w tym miejscu szczegółowy kontekst uzasadniający jej wybór, według autora, hipoteza ta „oferuje nową ożywczą perspektywę spojrzenia na ewolucję seksualną piękna"’3. W jej perspektywie akcentuje się teorię doboru płciowego, mylnie przy tym traktowaną jako teorię podważającą prawdziwość adaptacjonizmu w drodze doboru naturalnego, stanowiącego rdzeń tradycyjnie pojmowanego ewolucjonizmu. Według Pruma adaptacjonizm daje niepełny obraz „ewolucyjnej innowacji”. Aby zrozumieć mechanizmy pojawiania się nowych jakościowo zachowań (,innowacji estetycznej”), niezbędne staje się odwo-

${ }^{2}$ Przy czym powołuje się także na liczne opracowania. To też świadczy o niezwykłej erudycji autora.

${ }^{3}$ R.O. Prum, Ewolucja piękna. Jak darwinowska teoria wyboru partnera kształtuje świat zwierzat $i$ nas samych, tłum. K. Skonieczny, Kraków 2019, s. 85. Prum na wielu stronach odwołuje się do tej hipotezy. 
łanie do teorii doboru płciowego ${ }^{4}$. Dotyczy to szczególnie ewolucji wrażliwości estetycznej ptaków i wrażliwości estetycznej ludzi (ewolucji piękna), które wiążą się z wolnością wyboru partnera (autonomią seksu). Adaptacjonizm wiązany tylko z doborem naturalnym łączy bowiem reprodukcję z przemocą seksualną rozumianą jako niemożliwość wyboru partnera. Zasadność paraleli między ptakami i ludźmi staje się jeszcze bardziej oczywista, gdy hipotezę „Piękno się Zdarza” autor uzupełnia nie mniej kontrowersyjną hipotezą „Przyjemność się Zdarza”.

Lektura książki uzmysławia, że hipoteza ta jest także filozoficzną ideą, a nie tylko roboczą hipotezą w naukach biologicznych. Konfrontując ją z owym akademickim pojmowaniem teorii ewolucji, pojawia się też problem metodologiczny i problem z dziedziny filozofii nauki związany z tradycją uprawiania wiedzy naukowej. Piszę o tym w dalszej części.

W świetle hipotezy „Piękno się Zdarza” istnieje ścisły, ewolucyjnie ukształtowany związek między ornamentyką, rytuałami godowymi, struktura relacji partnerskich oraz anatomią a „preferencjami estetycznymi” powiązanymi z wolnością wyboru partnera seksualnego i to niezależnie od typu owych relacji. Odnosi się to głównie do płci, która dokonuje wyboru partnera seksualnego, a więc w zdecydowanej większości gatunków ptaków do samic. Łącząc hipotezę „Piękno się Zdarza” z ideą „autonomii seksualnej” ptaków i ludzi oraz ewolucją wszystkich cech związanych z biologia rozrodu, Prum pisze: „Pojęcie seksualnej autonomii zapewnia wgląd nie tylko w ewolucję mechanizmów obronnych przeciwko przemocy seksualnej i wymuszaniu kopulacji, ale również ewolucję innych, oddzielnych ścieżek radzenia sobie z problemem konfliktu płciowego". A więc „ewolucja seksualna piękna” i „ewolucja mechanizmów obronnych" funkcjonuje paralelnie i dlatego też można mówić o koewolucji. W kolejnych rozdziałach autor zajmuje się tym problemem w odniesieniu do ptaków, a w rozdziałach 10-11 — do ludzi.

Jak jednak owe „mechanizmy obronne” dotyczące ewolucji zachowań seksualnych, a więc dotyczace sfery behawioralnej, połączyć z ewolucją anatomii narządów płciowych i fizjologią związaną z rozrodem, a więc ze sferą fizyczną? Pomijając szczegóły, można odwołać się do fragmentu książki stanowiącego w pewnym sensie podsumowanie: „W ewolucji seksualnej autonomii ptaków uczestniczą zasadniczo dwa mechanizmy”, pierwszy polega na tym, że „samice wykształciły w drodze ewolucji fizyczne mechanizmy obronne w celu obniżenia efektywności wymuszonej kopulacji”, co zapobiega ,wymuszonemu zapłodnieniu”6. W drugim przypadku polega na tym, że „ten sam estetyczny wybór partnera [prowadzi] do transformacji samców tak, aby ułatwić samicom korzystanie z autonomii seksualnej"”. Przejawia się on w ,preferencji dla wysoce energicznych samców, wykonujących dramatyczne, złożone, wysublimowane i wielosensoryczne popisy"8, takie jak śpiewy, dźwięki

4 Ibidem, s. 138. Autor wskazuje przy tym, iż teoria doboru płciowego ma swoje korzenie w dziele Karola Darwina O pochodzeniu człowieka. Por. np. J.A. Endler, Natural Selection in the Wild, New Jersey 1986, rozdz. Restricted Meanigs of "Natural Selection".

5 R.O. Prum, op. cit., s. 202.

6 Ibidem, s. 314.

7 Ibidem, s. 315.

8 Ibidem. 
wydawane za pomocą piór, tańce czy budowanie altanek. Tak więc owa autonomia $\mathrm{w}$ pierwszym przypadku związana jest z ewolucją anatomiczną samic, w drugim ze zmianą zachowań godowych i społecznych samców. W tym drugim przypadku taka społeczna kontrola nie przynosi samicy żadnej bezpośredniej korzyści, ale za to umożliwia ,rozszerzenie swojej wolności seksualnego wyboru i sukcesu reprodukcyjnego"9. Prum łączy sferę „autonomii”, „piękna” i ,anatomii”, twierdząc, że „autonomia seksualna stanowi ewolucyjny silnik napędowy piękna"10. Mamy zatem przykład sprzężenia zwrotnego: pierwotny instynkt reprodukcyjny zapewniający przekazanie genów, wiążący się z ,gwałtem” i „przemocą”, jest „konfrontowany” $z$, domniemanym, istnieniem preferencji estetycznych i seksualnych samic (niekiedy i samców) w wyborze partnera. To zaś stanowi przeciwieństwo seksualnego przymusu i aktywną przed nim obronę. Mamy więc do czynienia z klasycznym przykładem konfliktu, walki płci. W konsekwencji prowadzi to do ewolucji odpowiednich strategii rozrodczych mających zapobiegać ,gwałtom”, strategii zarówno w sferze anatomicznej, jak i behawioralnej. Prowadzi to do autonomii wyboru partnera. Sukces ewolucyjny, związany według Pruma z wolnością wyboru oraz niezgodą na gwałt i przemoc, polega na tym, że eskalacja przemocy musiałaby w końcu doprowadzić do wyginięcia gatunku. Ale, podkreślmy to raz jeszcze, przy założeniu, że funkcjonuje autonomia (gatunkowa i indywidualna) w sferze estetycznej preferencji i estetycznej wrażliwości ptaków ${ }^{11}$.

Zatem tylko w perspektywie ewolucyjnej, ale nie w ograniczonej do adaptacjonizmu przez dobór naturalny, lecz w rozszerzonej o teorię doboru płciowego, powiązanego z estetyczną wrażliwością i estetycznymi preferencjami, wydaje się uzasadnione przejście od biologicznego (fizjologiczno-anatomicznego) aspektu do behawioralnych implikacji, aż po kontekst kulturowy, cywilizacyjny i antropologiczny. To nadaje sens łączeniu odmiennych poziomów zmian ewolucyjnych i wnioskom płynącym z ich interpretacji, które uzasadniają paralele między światem ptaków i ludzi. Wyjaśniając swoje poglądy, Prum odwołuje się do Richarda Dawkinsa: „Ale dlaczego samice ludzi miałyby ewoluować tak, by preferować dłuższe penisy o większym obwodzie i charakterystycznym kształcie? Odpowiedzią jest oczywiście seksualna przyjemność w jej wielu wymiarach"12.

Pozostają jeszcze, wspomniane wcześniej, polityczne i metodologiczno-filozoficzne aspekty poruszane przez autora, które sprawiają, że tę książkę warto zarekomendować w czasopiśmie filozoficznym. Prum pisze o tym, jak funkcjonuje i jak jest „praktykowana” obecnie nauka, o tym, jak bywa uwikłana w polityczne spory i jak jest ona „paradygmatyczna”. Wspominając o swoich perypetiach wydawniczych, kreśli czytelnikowi obraz kultury naukowej wspólnoty, jej „blaski i cienie”. Każdy, kto — choćby tylko powierzchownie — zna historię nauki przynajmniej od czasów nowożytnych, wie, jak z czasem wiedza naukowa staje się uzależniona od polityki, a następnie od ekonomii ${ }^{13}$. W XVII i XVIII wieku takie związki miały jeszcze

\footnotetext{
9 Ibidem.

10 Ibidem, s. 228.

11 Warto podkreślić raz jeszcze, że dotyczy to także innych zwierząt.

12 Ibidem, s. 279.

13 Por. np. Y.N. Harari, Sapiens. Od zwierząt do bogów, tłum. J. Hunia, Kraków 2019.
} 
akcydentalny charakter, później owa zależność stała się nie tylko regułą, ale warunkowała uprawianie nauki i jej egzystencję. A tym samym - egzystencję uczonych. Uzmysławiajacc czytelnikowi, że nie jest to tylko historia, Prum pokazuje, jak współcześnie polityka przenika do nauki, jak jest w niej wszechobecna. Uświadamia także, że wpływ polityki na cele, metody badań oraz na sugerowane społeczne oczekiwania efektów są przemożne, ponieważ wiążą się z dystrybucją pieniędzy ${ }^{14}$. Można pokusić się o stwierdzenie, że polityka pozbawiona wpływu na przydział środków finansowych straciłaby wiele ze swojej skuteczności.

W tej kwestii Prum odwołuje się do osobistych doświadczeń, opisując presję, jakiej był poddany. Po reelekcji Baracka Obamy w 2013 roku i „fiasku negocjacji" między republikanami i Białym Domem dotyczącym finansów celem ataków stały się badania naukowe, właściwie wybrane tematy i dziedziny nauki. Prum pisze następująco: „republikanie zwrócili uwagę na jeden ze swoich ulubionych tematów - marnotrawstwo rządowych pieniędzy. Właśnie w taki sposób prowadzone [...] badania na temat konfliktów płciowych i ewolucji anatomii genitalnej kaczek znalazły się w samym środku miniskandalu"15 wywołanego przez zarzut „marnotrawienia” pieniędzy podatników. Efekt był taki, że „Spośród trzydziestu miliardów zmarnowanych dolarów [...] »Post « postanowił wyróżnić w nagłówku jedną tysięczną procenta przeznaczoną na nasze badania. Z jakiegoś powodu kombinacja pieniędzy, seksu i władzy [...] sprawiła, że tematowi nie można się było oprzeć"16. W efekcie badaniom Pruma nadano podtekst seksualny. Konkludując, autor stwierdza, że tego rodzaju badania „prowadzą do istotnych odkryć ewolucyjnych, z których być może niektóre mają bezpośrednią wartość praktyczną" choćby dla przemysłu farmaceutycznego ${ }^{17}$.

Warto przy tym zwrócić uwagę na fakt, że tego rodzaju zarzuty wiążą się ze stanowiskiem, jaki zajmuja politycy, i są najczęściej elementem szerszego sporu politycznego (w tym przypadku republikanie vs demokraci).

Metodologiczno-filozoficzny kontekst jest również wielowątkowy. Na przykład czytelnika może zaintrygować fragment angielskiej wersji tytułu, który w całości brzmi następujacco: The Evolution of Beauty. How Darwin's Forgotten Theory of Mate Choice Shapes the Animal World — and Us. Nasuwa się od razu pytanie, co zostało w niej ,zapomniane"? Oczywiście nie cała teoria Darwina. Wspominany już „adaptacjonizm przez dobór naturalny" jest znany i akceptowany (,zaadaptowany") przez wszystkich ewolucjonistów, czyli dziś przez zdecydowaną większość biologów. Ale — zdaniem Pruma — został zapomniany jej istotny aspekt, mianowicie teoria doboru płciowego. Autor odwołuje się do tej teorii, ponieważ, jak już wspomniałem, wedle niego adaptacjonizm nie wyjaśnia satysfakcjonująco wielu aspektów biologii rozrodu ptaków, a także ludzi. O eksplanacyjnej i kulturowej randze teorii doboru płciowego Prum pisze, odnoszac się do tytułu książki Daniela Dennetta Niebezpieczna idea Darwina: „Ja chciałbym zaproponować tezę, że naprawdę nie-

\footnotetext{
14 Ibidem, cz. 3. Zjednoczenie ludzkości i cz. 4. Rewolucja naukowa.

15 R.O. Prum, op. cit., s. 194.

16 Ibidem, s. 196.

17 Ibidem, s. 197.
} 
bezpieczną ideą Darwina jest ewolucja estetyczna poprzez wybór partnera"18. Ten aspekt teorii ewolucji został skrytykowany i odrzucony nawet przez najzagorzalszych zwolenników teorii Darwina, którzy wiążą ją z adaptacjonizmem. W efekcie „darwinowska teoria wyboru partnera była od tego czasu często uciszana, dezinterpretowana, redefiniowana i zapomniana"19. Taka selektywna akceptacja treści teorii ewolucji generuje konsekwencje wykraczające poza czysto rozumianą biologię. Wyrugowanie doboru estetycznego z teorii ewolucji (powiązanej wówczas tylko z adaptacjonizmem w ramach doboru naturalnego) nieuchronnie, według Pruma, prowadzi do koncepcji eugeniki: staje się ona wówczas logiczną konsekwencją walki o byt i przetrwanie „lepszych genów”. Tymczasem teoria doboru naturalnego i hipotezy „Piękno się Zdarza” tłumaczy, dlaczego przyroda neutralizuje konflikty, dzięki czemu życie może trwać. To efekt dążenia do autonomii, realizowanego na drodze różnych strategii. Ale Prum wskazuje tė̇, że ów konflikt może trwać, gdy jest podsycany pozabiologicznymi, kulturowymi, czynnikami: religijnymi, politycznymi, ale także scjentystycznymi. Nauka „, służbie” polityki nie jest czymś wyjątkowym: dziś wnioski ekologii są nieustannie wprzęgane w bieżącą politykę.

Odwołanie się Pruma do hipotezy marginalizujacej wpływy preferowanej teorii adaptacjonistycznej i tłumaczacej zmianę zachowań godowych pewnego gatunku ptaka w kategorii „estetycznych preferencji” spowodowało, że autor musiał usunąć ten fragment pracy, by artykuł mógł się ukazać w branżowym czasopiśmie ${ }^{20}$. Śmiała teza Pruma nie spotkała się z aprobatą konserwatywnych recenzentów i redaktorów czasopisma. Wydawałoby się jednak, że nauka powinna opierać się na konfrontacji różnych hipotez (teorii) i argumentów, a tymczasem taka konfrontacja między tradycyjnym pojmowaniem mechanizmów ewolucji jako adaptacji przez dobór naturalny a zaproponowaną przez Pruma odważną teorią ,estetycznych preferencji" i argumenty na jej rzecz nie przekonywały środowiska związanego z czasopismem ${ }^{21}$. Tym samym, moim zdaniem, zostaje podważony nie tylko pewien model związany z funkcjonowaniem współczesnej nauki, ale także nasze wyobrażenia o tym, jak powinni współcześnie działać uczeni.

Można odnieść wrażenie, że idea Pruma, wiążąca wrażliwość estetyczną z fizjologią i anatomią, jest redukcjonistyczna. Uważam, że jest wręcz odwrotnie. Sprzężenie między tymi elementami jest oczywiste, ale nadrzędność estetyzacji jest już mniej uchwytna. Zarówno fizjologia, anatomia czy też niektóre zachowania seksualne są wtórne względem owej potrzeby doznań estetycznych i autonomii ich preferencji. Mają one swoje źródło w psychice, a u człowieka także w sferze intelektualnej. Owe potrzeby i preferencje są odpowiedzią, są egzemplifikacją potrzeb psychicznych i intelektualnych, a nie tylko reakcją na seksualne popędy. Na ile w świecie ptaków, a ogólniej w świecie zwierzęcym owa estetyzacja wiąże się z intelektem - to pytanie tak nowe jak nowe jest domniemanie, że zwierzęta mogą posiadać intelekt, a nie tylko instynkty. Poza tym badania uzmysławiają uczonym,

\footnotetext{
18 Ibidem, s. 26.

19 Ibidem.

20 Ibidem, s. 77-78.

21 Ibidem, s. 83.
} 
że ów przysłowiowy „ptasi móżdżek” kryje zadziwiająco bogatą psychikę i rozwinięty, zindywidualizowany gatunkowo i osobniczo umysł ${ }^{22}$. Nie od dziś mówi się o ptakach, że mają także osobowość.

Zastanówmy się również, dlaczego idea wrażliwości estetycznej zwierząt budzi takie wątpliwości? Odwołując się do poglądu Darwina na „ewolucyjne pochodzenie piękna", Prum akcentuje konsekwencje Darwinowskiej perspektywy. Otóż w jej ramach należy uznać, że „zwierzęta ewoluowały tak, by być pięknymi dla siebie”, a to oznacza, iż organizmy są aktywnymi uczestnikami w ewolucyjnych grach, a nie tylko biernymi obiektami zewnętrznych, bezosobowych sił doboru naturalnego. Skoro zaś są aktywne, to można podejrzewać, że owe preferencje, którymi dysponują, są intencjonalnie ukierunkowane. A zatem może pojawić się „podejrzenie”, że ptaki (a także niektóre ssaki) moga funkcjonować na jakimś poziomie świadomości (nie mówię tu o samoświadomości). To jednak kłóciłoby się z poglądami znacznej części ludzi, zwłaszcza tych o konserwatywnych, antropocentrycznych przekonaniach. Co więcej, jeśli uznamy, że ukierunkowana wrażliwość estetyczna jest jakąś własnością świadczącą o posiadaniu umysłu, a nie tylko mózgu i pierwotnej sfery psychicznej, to tym samym świadczyłaby o możliwości kreowania jakichś innych wyższych potrzeb. W konsekwencji powodowałoby, że musielibyśmy uznać ptaki i inne zwierzęta za organizmy obdarzone poczuciem sprawiedliwości, dobra, śmierci itp. i że owe ukierunkowane preferencje dodatkowo umożliwiałyby wartościowanie wyższych potrzeb ${ }^{23}$. W tym kontekście pojawić się więc musi pytanie o różnicę między ludźmi a zwierzętami. I o to, na czym miałaby ona polegać.

Odczuwanie doznań estetycznych u ludzi wiąże się z ich świadomością i samoświadomością, a w dodatku osadzone jest w kulturowym i społecznym kontekście. To, czy kultura owe odczucia i potrzeby wzmacnia, czy tė̇ je tłumi; czy je reglamentuje i kontroluje ze względu na płeć, status społeczny, ekonomiczny, czy też pozostawia swobodnemu wyborowi; czy traktuje je jako towar podlegający licytacji, czy też jako naturalną własność i skłonność, oraz to, jak bardzo wiąże je z seksualnymi praktykami, decyduje w konsekwencji o swobodzie i wolności, także seksualnej, jednostek. Zdarza się bowiem, że kultura owe potrzeby i wolności (nomen omen) gwałci.

Jak widzimy, problem związany z uznaniem estetycznej wrażliwości ptaków wiąże się z kwestiami metodologicznymi i antropologicznymi. W tym pierwszym przypadku wynika z konfrontacji adaptacjonizmu w świetle doboru naturalnego z koncepcją doboru płciowego (z estetyczną wrażliwością „w tle”). W drugim

${ }^{22}$ Por. np. N. Emery, Ptasia inteligencja, tłum. D. Graszka-Petrykowski, Warszawa 2018; B. Heinrich, Umyst kruka, tłum. M. Szczubiałka, Wołowiec 2018.

${ }^{23} \mathrm{~W}$ istocie współczesne badania nad zwierzętami uzmysławiają, że tak jest. Choć należy pamiętać, że u człowieka owe potrzeby i odczucia są znacznie bardziej rozbudowane i wiążą się z ich świadomością i samoświadomością. Co więcej, w powyższym kontekście należy zadać pytanie o to, czy wrażliwość estetyczną, moralną i etyczną, rozważaną w perspektywie ewolucyjnej, można rozpatrywać niezależnie? Czy też należy te wartości traktować jako koewoluujące i wzajemnie się warunkujące. Tę kwestię stawia Adam Chmielewski w artykule Piękno i obowiazek. Etyka ewolucyjna a estetyka Darwinowska, „Lectiones \& Acroases Philosophicae” 3 (2010). Teza tej pracy jest jednoznaczna: wartości te są, ,komplementarne", inaczej nie można zrozumieć ich biologicznej genezy.

Studia Philosophica Wratislaviensia, vol. XV, fasc. 4 (2020)

(C) for this edition by CNS 
zaś z ideą głoszącą podobieństwo mechanizmów funkcjonujących w sferze seksu w świecie ptaków i ludzi ${ }^{24}$ oraz ze znaczeniem kultury dla autonomii jednostki, także w kwestii wyboru partnera. Skoro bowiem „proces koewolucji estetycznej odbywa się poprzez seksualną sprawczość osobników [...] wskazuje kobiety jako aktywne sprawczynie ewolucji ich własnej zdolności do osiągania przyjemności płynącej z orgazmu" ${ }^{\prime 25}$, to tym samym związki między estetycznymi preferencjami i przyjemnością a anatomią ${ }^{26}$ funkcjonują u ludzi — wedle Pruma - w analogiczny sposób jak u ptaków. Pozwolę sobie ostatnią uwagę podsumować w następujący sposób. Pisząc o ewolucji piękna, autor przechodzi od ewolucji estetycznej ptasich samic do idei wolności seksualnej kobiet. To sformułowanie, akcentujące przede wszystkim ową wspólnotę świata zwierząt i ludzi, nie „zagraża” — tak sądzę - poczuciu odrębności (wyjątkowości) naszego gatunku. Chcę uzmysłowić w ten sposób, iż lektura książki Pruma nieustannie wymusza refleksje nad ludzką naturą i kulturą oraz nad funkcjonowaniem współczesnej nauki.

Jako miłośnik ptaków, śledzący również meandry ornitologii (rozumianej jako wiedzy naukowej), zdaję sobie sprawę, iż mogę narazić się na zarzut subiektywizmu. Mimo tego, a może właśnie dlatego tym bardziej rekomenduję książkę Pruma osobom, dla których świat ptaków, ornitologia, a także filozofia nauki nie stanowią przedmiotu szczególnego zainteresowania. Książka Pruma jest przykładem wartościowej literatury naukowej i popularno-naukowej, łączącej szczegółowe zagadnienia biologiczne (oparte na własnych obserwacjach), przedstawiane w szerokim kontekście innych prac naukowych, z problemami antropologicznymi i kulturowymi. Fascynująca książka Pruma dotyczy wrażliwości estetycznej i seksu, a więc tego, co nierozerwalne i co łączy świat zwierząt i ludzi.

\footnotetext{
24 Por. R.O. Prum, op. cit., s. 279.

25 Ibidem, s. 309.

26 Por. ibidem, s. 279, 265, 314, passim.
} 